\title{
Epithelioid Myoepithelioma of the Parotid Gland: A Histopathological and Immunohistochemical Study
}

\author{
Mioepitelioma Epitelioide de Glándula Parótida: \\ Estudio Histopatológico e Inmunohistoquímico
}

\author{
María Elena Samar*; Rodolfo Esteban Avila**; Marta Susana Furnes**; Ismael Bernardo \\ Fonseca**; Hugo Oscar Juri**; Luis Augusto Olmedo* \& William J. Anderson***
}

SAMAR, M. E.; AVILA, R. E.; FURNES, M. S.; FONSECA, I. B.; JURI, H. O.; OLMEDO, L. A. \& ANDERSON, W. J. Epithelioid myoepithelioma of the parotid gland: A histopathological and immunohistochemical study. Int. J. Med. Surg. Sci., 1(2):177-183, 2014.

SUMMARY: The diagnosis and classification of salivary gland tumours is complicated by the wide variety of histological types that exist. Many authors attribute this complexity to the myoepithelial component of these tumours. The objective of this study is to evaluate the histological and immunohistochemical properties of a parotid gland myoepithelioma, in order to further our understanding of the differential diagnosis of salivary gland tumours which contain myoepitheliocytes. Histological specimens were analyzed using haematoxylin and eosin (H\&E), periodic acid Schiff (PAS), Cason, Alcian blue, toluidine blue, a-SMA, p63 and ki67. The tumour examined was completely encapsulated, with solid cellular regions delimitated by a stroma. The stroma consisted of wide acidophilic and PAS-positive hyaline septae with areas of metachromasia. The tumour cells contained clear cytoplasm and round nuclei with lax chromatin, although some had more elongated nuclei and occasional dense chromatin. Neither cellular atypia nor mitotic figures were observed. Immunostaining was positive for a-SMA and p63, while it was negative for ki67. The histological characteristics of the tumour analyzed were consistent with a benign myoepithelioma, a rare tumour which represents less than $1 \%$ of salivary gland neoplasias. Immunostaining confirmed the morphological diagnosis of myoepithelioma. The absence of cytological changes and mitosis and its encapsulation differentiate it from its malignant counterpart. In comparison to pleomorphic adenoma, the myoepithelioma does not demonstrate ductal differentiation or chondromyxoid stroma. Importantly, the epithelial-myoepithelial carcinoma does develop tubular structures not seen in myoepithelioma. p63, which may act as an oncogene, is expressed within the nuclei of myoepitheliocytes of normal salivary glands. Its expression is retained in tumour myoepitheliocytes and thus it may play a role in oncogenesis.

KEY WORDS: Salivary glands; Myoepithelioma; Histopathology; Tumour.

\section{INTRODUCTION}

Salivary gland tumours are rare neoplasias of the head and neck. There is a wide variety of histological types and subtypes which complicates their classification and diagnosis (Ellis \& Auclair, 2008). Many authors attribute this complexity to the myoepithelial component of these tumours (Savera \& Zarbo, 2004). Salivary gland tumours which most frequently contain myoepitheliocytes include pleomorphic adenoma, adenoid cystic carcinoma, and epithelial-myoepithelial carcinoma (Ellis \& Auclair).

The tumours formed exclusively of myoepitheliocytes, the myoepitheliomas, are rare and represent less than $1 \%$ of all salivary

* Faculty of Dentistry, Universidad Nacional de Córdoba, Córdoba, Argentina.

** Faculty of Medical Sciences, Universidad Nacional de Córdoba, Córdoba, Argentina.

*** John Radcliffe Hospital, Oxford, United Kingdom.

Grant 162/12. Secretaría de Ciencia y Tecnología. Universidad Nacional de Córdoba, Argentina. 
gland tumours (García Ortega et al., 2001). The myoepithelioma is a benign, wellcircumscribed and encapsulated tumour, which generally occurs in the parotid gland, and less frequently, in the minor salivary glands (Ferri et al., 2006; Gun et al., 2009). It has a low incidence of local recurrence and metastasis (Karli, 2012). The myoepitheliocytes observed in these tumours are of varying cellular morphology, as demonstrated by Batsakis et al., in 1983 using light microscopy (Batsakis et al., 1983; Sperandio et al., 2011).

The predominant cells within a myoepithelioma may be either spindle, plasmacytoid, epithelioid or clear cell in morphology. A tumour may contain one specific cellular type, or consist of a mixture of different histological patterns (Sperandio et al.).

Myoepithelioma was first described by Sheldon in 1943, and had been considered a subtype of pleomorphic adenoma up until 1991, when it was re-classified by the World Health Organization (WHO) as an independent entity (Ferri et al.; Ellis \& Auclair). Despite this, a number of authors maintain that these lesions are two forms of the same entity.

Ferri et al., believe that this tumour may represent one end of a biological spectrum which also includes pleomorphic adenomas and non-membranous basal cell adenomas. According to Torres Gómez et al. (2004), the salivary gland myoepithelioma is a controversial tumour in terms of its morphology, and they consider it a monomorphic variant of the pleomorphic adenoma with a differentiation of myoepitheliocytes and an absence of ductal components.

Politi et al., (2005) also believe that salivary gland adenomas are part of a spectrum in which the myoepithelioma and the monomorphic adenoma are at each extreme, and in between there is a wide range of pleomorphic adenomas.

Santos et al., (2011) point out that although the myoepithelioma has previously been considered a variant of pleomorphic adenoma with exclusive myoepithelial differentiation, many authors currently believe that it is a distinct pathological entity which behaves differently. Specifically, Santos et al., highlight its tendency to be more aggressive than the pleomorphic adenoma.

The malignant counterpart of this tumour is the myoepithelial carcinoma (Ellis \& Auclair). Ren et al., (2011) explain that the myoepithelial carcinoma develops principally in the parotid gland, as well as the nasopharynx, paranasal sinuses and nasal cavity, while it arises less commonly in the palate. Myoepitheliocytes tumours, whether benign or malignant, develop within the parotid gland $40 \%$ of the time, while $21 \%$ are localised to the palate (Gun et al.; Zormpa et al., 2011).

On the other hand, a rare case of epithelioid myoepithelioma of the hard palate was described by Kasamatsu et al. (2013). Saliba et al., (2012) reported the first case of myoepithelial carcinoma of the parotid with extensive local invasion of the facial nerve and cervical lymph node metastases in a 7-yearold child.

The objective of this study was to evaluate the histological and immunohistochemical properties of a parotid gland myoepithelioma, in order to further our understanding of the differential diagnosis of salivary gland tumours which contain myoepitheliocytes.

\section{MATERIAL AND METHOD}

Patient. A 21-year-old woman was seen in clinic with a six-month history of a painless swelling of the left parotid gland. The mass was non-tender on palpation and she was otherwise asymptomatic.

Methods. Serial histological sections were embedded with paraffin and stained with H\&E, PAS, Cason's trichrome and Toluidine blue. In order to confirm the myoepithelial origin of neoplastic cells they were immunostained with p63 and alpha-SMA. ki67 was employed to identify cells in the cell cycle. Expression was only classed as positive if more than $10 \%$ of 
cells within a high-power field were labeled, and thus expression was determined negative if this figure was not reached. Immunohistochemical techniques were carried out on paraffinembedded tissue of $4 \mu \mathrm{m}$ thickness using a Dako LSAB+ kit (Samar et al., 2004).

\section{RESULTS}

Macroscopic. A surgical specimen of $5 \times 3.5 \times 2.8$ $\mathrm{cm}$ was obtained which was yellow in color and had a smooth external surface. A $3 \mathrm{~cm}$ area of fibroadipose tissue was identified at one extremity. On dissection, a well-demarcated yellow-brown nodular tumour of $3.7 \times 3.3 \times 2.3 \mathrm{~cm}$

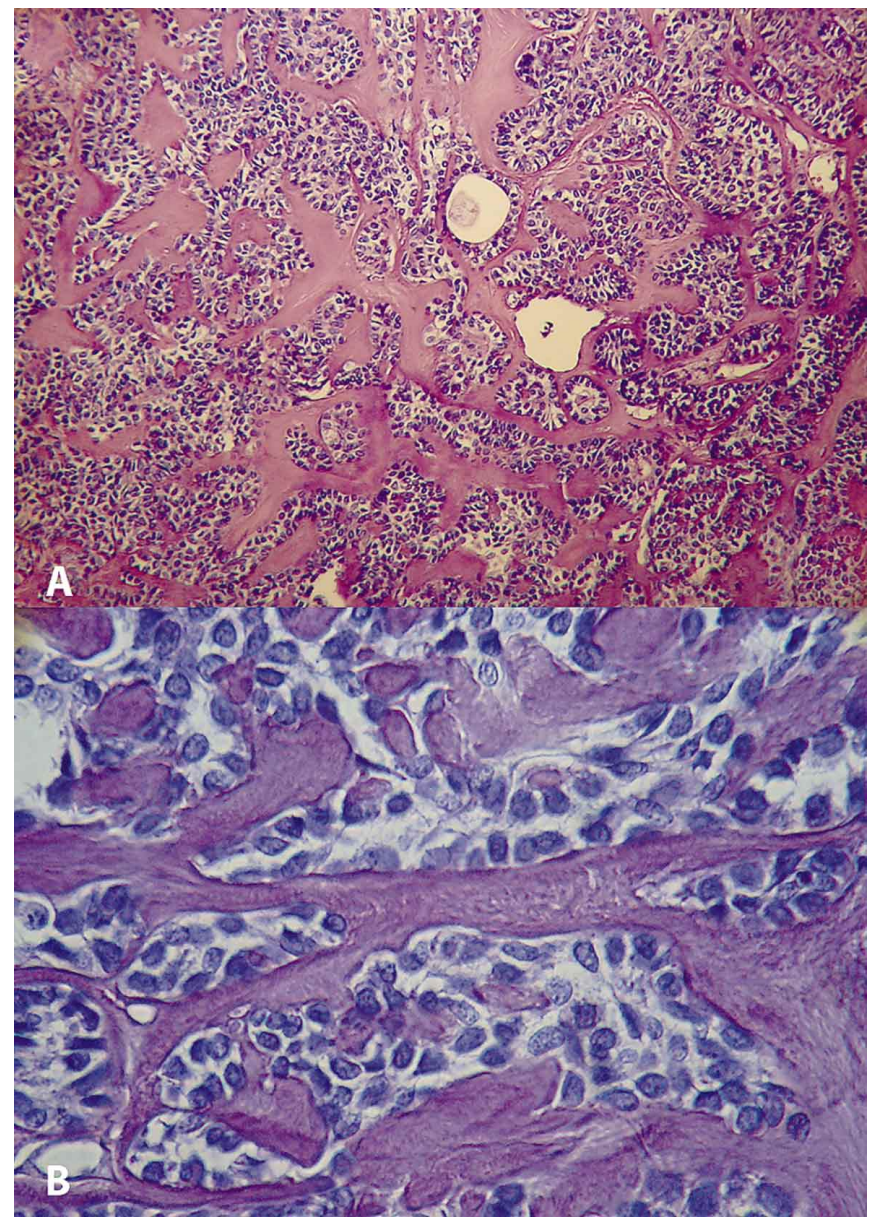

Fig. 1. Epithelioid myoepithelioma of the parotid gland. A.- Nests and strands of cells demarcated by acidophilic hyaline septae (H/E. 200x). B- Higher-powered image of the same specimen. Epithelioid tumour cells are seen with clear, weakly acidophilic cytoplasm, containing nuclei with lax chromatin (H/E. 400x). was observed. Tumour-free margins were not demonstrated.

Microscopic. The nodular lesion described above was completely encapsulated by fibrous connective tissue. The tumour parenchyma was arranged in discrete nestlike regions attached to strands of cells. It was demarcated by a stroma consisting of wide, acidophilic and PAS-positive hyaline septae (Figs. 1A and 2). It was moderately positive with Cason. Dispersed metachromatic areas were also observed. The blood vessels of the stroma were dilated and congested.

The tumour cells were epithelioid with a moderate amount of clear cytoplasm which was weakly eosinophilic (Fig. 1B). Round nuclei with euchromatin were generally seen, although some cells had more elongated nuclei and occasional dense chromatin was also observed. Neither cellular atypia, mitotic figures nor infiltrating growth were observed. The remaining parotid tissue was conserved with zones of lymphocytic infiltration, which constituted lymphoid nodules.

Immunostaining with alpha-SMA was intense in many areas of the tumour. Similar results were obtained with p63, which also gave an intense nuclear reaction of all tumour cells, permitting their diagnosis as myoepitheliocytes (Fig. 3). Staining with ki67 was negative, without stained nuclei.

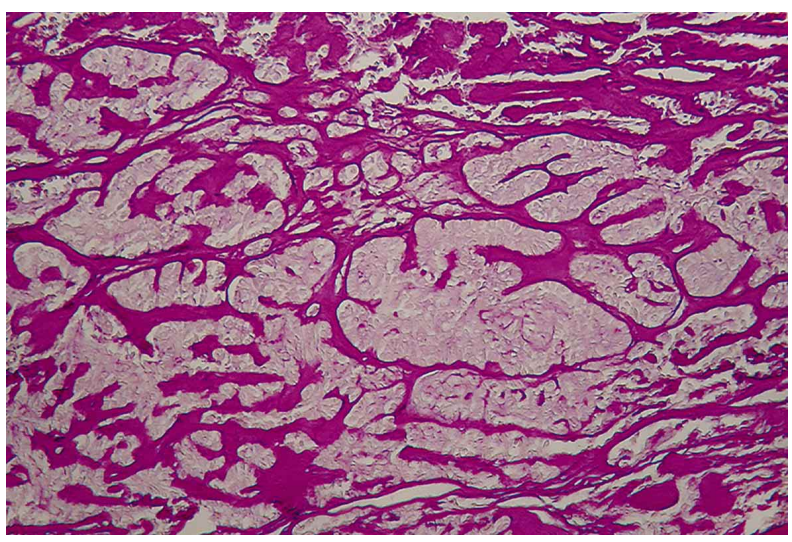

Fig. 2. Epithelioid myoepithelioma of the parotid gland. PAS-stained specimen highlighting wide, PAS-positive septae (200x). 


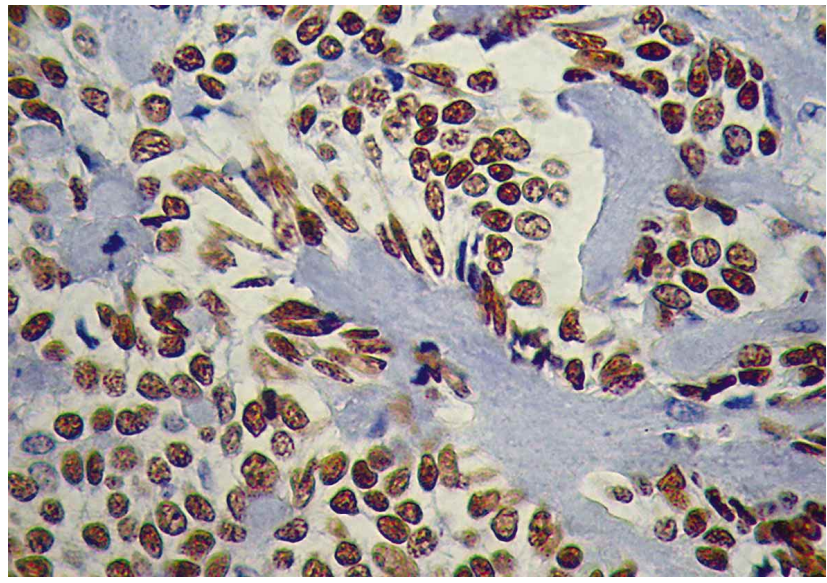

Fig. 3. Epithelioid myoepithelioma of the parotid gland. Positive nuclear reaction in myoepitheliocytes (p63. 400x).

\section{DISCUSSION}

Myoepitheliocytes are contractile epitheliocytes that are found in many normal tissues with a secretory function, principally the salivary glands (Avila et al., 2008). Myoepitheliocytes are present in a heterogeneous group of benign and malignant salivary gland tumours, whose correct diagnosis is a challenge for head and neck specialists such as pathologists, surgeons and dentists.

Myoepitheliomas had traditionally been described as tumours consisting of spindle myoepitheliocytes (Dardick et al., 1989). However, on the basis of morphology there are now four recognized tumour types, which include spindle, plasmacytoid, epithelioid and clear-cell variants (Kasamatsu et al.). Some authors have suggested that these cell types represent different stages of differentiation of the myoepitheliocytes (Hornick \& Fletcher, 2003).

In terms of morphology, plasmacytoid cells are polygonal, with eccentric nuclei and an abundant eosinophilic cytoplasm. Spindle cells are elongated with sharp ends and are arranged in interlooping fascicles similar to stroma (Sperandio et a/.). Epithelioid cells are either round or polygonal with central nuclei. They possess a variable quantity of eosinophilic cytoplasm and tend to be arranged in nests or strands. Finally, clear cells contain large quantities of PAS-positive glycogen while their cytoplasm is abundant and optically clear (Sperandio et al.).

Tumour cells and fibrohyaline or myxoid stroma can combine in different ways, which results in a wide spectrum of histological patterns seen in myoepitheliomas, as described by Ellis \& Auclair as well as Santos et al. This multiplicity of histological patterns coupled with the difficulty in identifying myoepitheliocytes with routine histological techniques can be resolved through the use of immunohistochemical markers (Garcia Ortega et al.).

\section{Various immunohistochemical markers}

have been proposed to diagnose myoepithelioma. However, Rastogi et al. (2008) explain that there is significant variability in their expression, probably due to the fact that neoplastic myoepitheliocytes demonstrate different grades of differentiation.

Making an accurate pathological diagnosis in this way is vital in determining the correct treatment and prognosis for the patient in concern.

The case that we report here corresponds histologically to an epithelioid-type myoepithelioma. Amongst the morphological variants of myoepithelioma, the epithelioid type has not been reported in the oral or maxillofacial region, according to Kasamatsu et al. We believe that this tumour subtype should be included in the differential diagnosis of salivary gland tumours with a myoepithelial component.

The principal differential diagnosis of myoepithelioma is with pleomorphic adenoma. The latter is the most common salivary gland tumour, and is characterized by the biphasic proliferation of epitheliocytes and myoepitheliocytes and a stromal component with myxoid and chondroid foci (Ellis \& Auclair).

The epitheliocytes are cuboidal, and arranged in ductal structures, thin sheets or trabeculae and may undergo squamous, sebaceous or oncocytic metaplasia. The myoepitheliocytes are spindle or plasmacytoid, and may lie within a chondromyxoid matrix or be arranged in isolated cellular nests (Ellis \& 
SAMAR, M. E.; AVILA, R. E.; FURNES, M. S.; FONSECA, I. B.; JURI, H. O.; OLMEDO, L. A. \& ANDERSON, W. J. Epithelioid myoepithelioma of the parotid gland: A histopathological and immunohistochemical study. Int. J. Med. Surg. Sci., 1(2):177-183, 2014.

Auclair). The myoepithelioma does not demonstrate epitheliocytes, ductal differentiation nor a chondroid/chondromyxoid stroma (Ren et al.).

The majority of myoepithelial tumours of the salivary glands are benign (Gun etal.). Their malignant counterpart is the myoepithelial carcinoma, a tumour characterised by a tendency to run an aggressive clinical course and recur despite adequate treatment (Mejía Hernández et al., 2013). It demonstrates nuclear atypia, a high proportion of mitotic figures, invasion of adjacent tissues and areas of necrosis, in addition to positive staining for ki67 (Jiang et al, 2012).

Jiang et al suggest that recurrence and metastasis are more frequent in myoepithelial carcinomas positive for p63 and ki67. However, it was felt that further series are needed to be evaluated in order to corroborate this finding. One malignant criterion proposed by Savera et al. (2000) is the histological identification of seven or more mitotic figures within a highpowered field. In the myoepithelioma, on the other hand, there is tumour encapsulation, absence of cellular pleomorphism and nuclear atypia, mitotic figures are rare and growth is non-invasive (Ren et al.).

Considering that growth of the tumour is highly variable and probably reflects its clinical course, we studied the expression of the cellular proliferation marker ki67, proving that the marker was negative. The ki67 antigen identifies proliferating cells within a tumour and the more it is present, the more aggressive the tumour. ki67 expression status therefore correlates with the tumour grade.

The histological structure of epithelialmyoepithelial carcinoma consists of ducts covered with a double layer of cells, an internal layer of epitheliocytes, and an external layer of myoepitheliocytes. The myoepithelioma does not develop such ducts nor the epitheliocytes as previously thought (Ellis \& Auclair). At times we must make a differential diagnosis between myoepithelioma with epithelioid and spindle cells and a biphasic synovial sarcoma. Both are cytokeratin-positive tumours, however the sarcoma is also positive for the marker vimentin, it displays nuclear abnormalities, mitotic figures, and the formation of pseudoglandular spaces similar to a fissure (Ortiz Rodríguez-Parets et al., 2008).

Another possible diagnosis includes paraglanglioma. When presented with a tumour containing epithelioid cells localized to a region in the neck, the use of neuron-specific enolase (NSE) immunohistochemistry allows us to rule out the presence of a paraganglioma, a tumour derived from neuroectoderm (Ellis \& Auclair).

On the other hand, p63 is a nuclear immunohistochemical marker of basal/somatic precursor cells in stratified epithelium and normal myoepitheliocytes of the salivary glands and breast (Reish-Filho \& Smith, 2002; Ortiz Rodríguez-Parets et al.). It regulates a number of cellular functions such as proliferation, survival and differentiation and thus may also act as an oncogene (Deyoug \& Elliosen, 2007; Jiang et al.). Its expression is retained in tumour myoepitheliocytes and it may therefore play a role in the oncogenesis of this tumour.

In conclusion, the histological and immunohistochemical characteristics of the tumour studied in this case were consistent with a diagnosis of epithelioid myoepithelioma with hyaline stroma. Further studies are required to elucidate the molecular mechanisms behind the expression of p63, not only in malignant tumours but also in benign tumours such as the myoepithelioma.

SAMAR, M. E.; AVILA, R. E.; FURNES, M. S.; FONSECA, I. B.; JURI, H. O.; OLMEDO, L. A. \& ANDERSON, W. J. Mioepitelioma epitelioide de glándula parótida: estudio histopatológico e inmunohistoquímico. Int. J. Med. Surg. Sci, 1(2):177183, 2014.

RESUMEN: Los tumores de glándulas salivales presentan amplia variedad de tipos histológicos lo que dificulta su clasificación y diagnóstico. Muchos autores atribuyeron su complejidad al componente mioepitelial de estas neoplasias. El propósito del presente estudio fue analizar con métodos histológicos e inmunohistoquímicos un mioepitelioma de parótida para contribuir a su diagnóstico diferencial con otros tumores que desarroIlan mioepiteliocitos. Los cortes histológicos se analizaron con H/E, PAS, Cason, Alcian blue, Azul de 
SAMAR, M. E.; AVILA, R. E.; FURNeS, M. S.; FONSECA, I. B.; JURI, H. O.; OLMEDO, L. A. \& ANDERSON, W. J. Epithelioid myoepithelioma of the parotid gland: A histopathological and immunohistochemical study. Int. J. Med. Surg. Sci., 1(2):177-183, 2014.

toluidina, a-SMA y p63 y ki67. El tumor, completamente encapsulado, estaba formado por nidos celulares sólidos delimitados por un estroma constituido por gruesos septos hialinos acidófilos, PAS positivos y con áreas de metacromasia. Las células tumorales presentaban un citoplasma claro y núcleos redondeados con cromatina laxa y algunos grumos de cromatina densa. Algunos núcleos eran elongados. No se observaron atipias celulares ni figuras de mitosis. La inmunomarcación fue positiva con a-SMA y p63. ki67 resultó negativo. Por sus características histológicas el tumor analizado es un mioepitelioma benigno, tumor raro que corresponde a menos del $1 \%$ de las neoplasias salivales. La inmunomarcación confirma el diagnóstico morfológico de mioepitelioma. La ausencia de alteraciones citológicas y mitosis y su encapsulación lo diferencian de su contraparte maligna. En relación al adenoma pleomórfico, el mioepitelioma no presenta diferenciación ductal ni estroma condromixoide. El carcinoma epitelial/ mioepitelial desarrolla estructuras tubulares, no observadas en el mioepitelioma. p63, que puede actuar como oncogen, se expresa en el núcleo de mioepiteliocitos de glándulas salivales normales. Su expresión es retenida en mioepiteliocitos tumorales, por lo cual podría participar en la oncogénesis de este tumor.

PALABRAS CLAVE: Glándulas salivales; Mioepitelioma; Histopatología.

\section{REFERENCES}

Ávila, R. E.; Samar, M. E.; Fonseca, I. \& Ferraris, R. Mioepitelioma de parótida: estudio histológico, histoquímico e inmunohistoquímico. Ini. Inv., 3: $1-7,2008$.

Batsakis, J. G.; Kraemer, B. \& Sciubba, J. J. The pathology of head and neck tumors: the myoepithelial cells and its participation in salivary gland neoplasia, part 17. Head Neck Surg., 5:222-33, 1983.

Dardick, I.; Cavell, S.; Boivin, M.; Hoppe, D.; Parks, W. R.; Stinson, J.; Yamada, S. \& Burns, B. F. Salivary gland myoepithelioma variants. Histological, ultrastructural, and immunocytological features. Virchows Arch. A Pathol. Anat. Histopathol., 416(1):25-42, 1989.

Deyoung, M. P. \& Elliosen, L. W. p63 and p73 in human cancer: defining the network. Oncogene, 26:5169-83, 2007.

Ellis, G. L. \& Auclair, P. L. Atlas of tumor pathology.
Tumors of the salivary glands. Washington, AFIP ed., 2008.

Ferri, E.; Pavon, I.; Armato, E.; Cavaleri. S.; Capuzzo, P. \& Ianniello, F. Myoepithelioma of a minor salivary gland of the cheek: case report. Acta Otorhinolaryngol. Ital., 26:43-6, 2006.

García Ortega, F. P.; Carcasés Ortiz, M. J.; Martínez Reig. S.; Bevia González, M. C.; Durán, R. \& Malluguiza Calvo, J. R. Mioepitelioma en glándulas salivales. Acta Otorrinolaringol. Esp., 52(3):269-72, 2001.

Gun, B. G.; Ozdamar, S. O.; Bahadir, B. \& Uzun, L. Salivary gland myoepithelioma with focal capsular invasion. Ear Nose Throat J., 88:1005-9, 2009.

Hornick, J. L. \& Fletcher, C. D. Myoepithelial tumors of soft tissue: a clinicopathologic and immunohistochemical study of 101 cases with evaluation of prognostic parameters. Am. J. Surg. Pathol., 27:1183-96, 2003.

Jiang, Y. H.; Cheng, B.; Ge, M. H. \& Zhang, G. The prognostic significance of $\mathrm{p} 63$ and ki67 expression in myoepithelial carcinoma. Head Neck Oncol., 4:9, 2012

Karli, R. Myoepitheliomas are rare tumors of the parotid gland: A case report and review of the literature. Univers. J. Med. Dent., 1:1-4, 2012.

Kasamatsu, A.; Shiiba, M.; Nakashima, D.; Shimada, K.; Higo, M.; Ishigami, T.; Ishige, S.; Ogawara, K.; Tanzawa, H. \& Uzawa, K. Epithelioid myoepithelioma of the hard palate. Oral. Maxillofac. Surg., 17:63-6, 2013.

Mejía Hernández, I. J.; Cano Valdéz, A. M.; De LeónTrenado, D. \& Luna Ortiz, K. Malignant myoepithelioma of the soft palate. Auris Nasus Larynx, 40:231-4, 2013.

Ortiz Rodríguez-Parets, J.; Bengoechea Miranda, O.; Muñoz Sing, I. R.; Mozota Núñez, J. R. \& Bullón Sopelana, A. Sarcoma sinovial: hallazgos morfológicos en un caso estudiado por punción aspiración con aguja fina. Rev. Esp. Patol., 41(2):131-3, 2008.

Politi, M.; Toro, C.; Zerman, N.; Mariuzzi, L. \& Robiony, M. Myoepithelioma of the parotid gland: case report and review of literature. Oral Oncol. Extra, 41:104-8, 2005.

Rastogi, S.; Modi, M.; Dhawan, V. \& Kumar, A. Myoepithelioma of the palate. A case report and review of literature. J. Clin. Diag. Res., 2:1095-9, 2008. 
SAMAR, M. E.; AVILA, R. E.; FURNES, M. S.; FONSECA, I. B.; JURI, H. O.; OLMEDO, L. A. \& ANDERSON, W. J. Epithelioid myoepithelioma of the parotid gland: A histopathological and immunohistochemical study. Int. J. Med. Surg. Sci, 1(2):177-183, 2014.

Reish-Filho, J. S. \& Schmitt, F. C. Taking advantage of basic research: p63 is a reliable myoepithelial and stem cell marker. Adv. Anat. Pathol., 9:2809, 2002.

Ren, J.; Liu, Z.; Liu, X.; Zhang, Z.; Li, Z.; Yang, Y.; Yang I.; Chen, Y. \& Jiang, S. Primary myoepithelial carcinoma of palate. World J. Surgical Oncol., 9:104-10, 2011.

Saliba, I.; El Khatib, N.; Nehme, A.; Nasser, S. \& Moukarzel, N. Metastatic parotid myoepithelial carcinoma in a 7-year -old boy. Case Rep. Pediatr., 2012:212746, 2012.

Samar, M. E. ; Avila, R. E. \& Esteban Ruiz, F. J. Técnicas histológicas. Córdoba, SeisC, 2004.

Santos, E. P. ; Cavalcante, D. R. ; Melo, A. U.; Pereira, J. C.; Gomes, M. Z. \& Albuquerque, R. L. Jr. Plasmocytoid myoepithelioma of minor salivary glands: report of case with emphasis in the immunohistochemical findings. Head Face Med., 7:24-9, 2011.

Savera, A. T. \& Zarbo, R. J. Defining the role of myoepithelium in salivary gland neoplasia. Adv. Anat. Pathol., 11(2):69-85, 2004.

Savera, A. T.; Sloman, A.; Huvos, A. G. \& Klimstra, S. D. Myoepithelial carcinoma of the salivary glands. A clinicopathologic study of 25 cases. Am. J. Surg. Pathol., 24(6):761-74, 2000.

Sperandio, F. F.; Giudice, F. S.; Pinto-Junior, D. D. \& de Souza, S. C. Myoepithelioma of the soft palate: a case report giving special attention to the differential diagnosis. J. Oral Maxillofac. Res., 2(1):e4, 2011.

Torres Gómez, F. J. ; Lag Asturiano, E. ; Torres Olivera, F. J. \& Villar Rodríguez, J. L. Mioepitelioma parotídeo. Estudio citológico, histológico e inmunohistoquímico. Rev. Esp. Patol., 37:437-42, 2004.

Zormpa, M.; Sarigelou, A. S.; Eleftheriou-Anthoula, S. ; Assamaki, S.; Kolokotronis, A. \& Kolokotronis, A. E. Plasmacytoid myoepithelioma of the palate: case report. Head Neck Pathol., 5:154-8, 2011.
Correspondence to:

María Elena Samar

Faculty of Dentistry

Universidad Nacional de Córdoba

Catamarca 1546 (5000)

Córdoba

REPUBLICA ARGENTINA

Email: samarcongreso@gmail.com

Received: 23-05-2014

Accepted: 12-06-2014 